\title{
Review: The effects of soil compaction on root penetration, pasture growth and persistence
}

\author{
J.R. CRUSH ${ }^{1}$ and E.R. THOM ${ }^{2}$ \\ ${ }^{1}$ AgResearch, Ruakura Research Centre, Private Bag 3123, Hamilton \\ ${ }^{2}$ DairyNZ, Private Bag 3221, Hamilton \\ jim.crush@agresearch.co.nz
}

\begin{abstract}
A review of the literature shows that soil compaction by stock treading has been an issue for New Zealand farmers for over half a century. Soil compaction restricts root penetration resulting in poor anchorage and susceptibility of plants to uprooting during grazing. In addition, access to moisture and soil nutrients is reduced which decreases the fitness of the sward under stress conditions. Mechanical treatment of compacted soil improves soil physical properties but beneficial effects on pasture growth have been less readily demonstrated. Options to reduce the impact of soil compaction on pasture persistency include better soil management to reduce the incidence and severity of compaction and, in the longer term, new grasses with root and shoot traits that mitigate the effects of compaction.
\end{abstract}

Keywords: roots, ryegrass, soil compaction, soil moisture, soil nutrients, trampling

\section{Introduction}

Treading of wet soils by dairy cattle causes soil compaction resulting in decreases in hydraulic conductivity, air permeability and macroporosity (Drewry et al. 2000a), and an increased proportion of large soil aggregates (Singleton \& Addison 1999). Soil compaction by treading has been known for decades (e.g. Sears 1956), and the effects of cattle treading on pasture and soil responses have been reviewed by Drewry et al. (2008). Loss of soil's natural capital due to intensification of pastoral agriculture was discussed by Mackay (2008). Soil compaction under grazing is a common problem, widely reported in New Zealand and overseas (e.g. Federer et al. 1961; Mullen et al. 1974; Willat \& Pullar 1984), with local variations in intensity controlled by soil type, soil moisture conditions, and stock class and stocking rate. Effects are most apparent between 50 and $100 \mathrm{~mm}$ soil depth (Singleton \& Addison 1999).

Smearing of the soil surface ("pugging") by treading under very wet conditions can substantially reduce pasture regrowth rates, with particularly damaging effects on clover. On a Te Kowhai soil at the DairyNZ No. 2 dairy farm near Hamilton, a single severe pugging event by dairy cows reduced ryegrass DM yield by
$37 \%$ and clover DM yield by $52 \%$ over the following 12 months (Menneer et al. 2005). Once pugged, the pasture remains susceptible to further pugging damage for months after the original event (Zegwaard 2006).

The increased penetration resistance of the compacted soil reduces the downward growth of grass roots (Chapman \& Allbrook 1987). For ryegrass this effect is mainly mechanical rather than being caused by the anoxic conditions typical of pugged and compacted soils, because, although ryegrass root growth is slowed, it is not stopped at soil oxygen levels that are prohibitively low for most other species (Gradwell 1967). Restrictions to root growth can be overcome if the compacted soil layer is treated by subsoiling or mechanical aeration (Houlbrooke 1996; Burgess 1998). Subsoiling increases soil macroporosity and air permeability, and reduces bulk density (Drewry \& Paton 2000; Drewry et al. 2000b; Burgess et al. 2000). However, these improvements have not always been associated with recorded increases in pasture growth in the short term. In some cases the lack of pasture growth response may have been caused by root damage making the sward susceptible to dry spells (Drewry \& Paton 2000), so timing of the soil treatment is important.

\section{Deleterious effects of impeded root growth}

Enforced shallow-rooting makes pasture plants susceptible to uprooting during grazing (Charles 1979); this is a major contributor to poor pasture persistence. The effect of limited root penetration is exacerbated by any root-damage caused by insect pests. Shallow rooting reduces access to subsoil moisture by forage grasses (Torbert et al. 1990), and hence the ability of swards to cope with dry conditions. The environmental footprint of the pasture increases, as the risk of nitrate leaching increases (Dunbabin et al. 2003) and the potential for carbon sequestration in the subsoil is reduced (Lorenz \& Lal 2005) when root penetration is limited.

Managing soils and pastures to optimise pasture persistence

Managing soils that are susceptible to damage

Soils differ in their resistance to treading and 
Figure 1 Percentage reduction in root dry weight (DW) at 4-8 cm soil depth compared with root DW at 0-4 $\mathrm{cm}$ for both Ruanui and Manawa ryegrasses under increasing soil compaction. Data from Edmond (1958). The arrow shows front hoof ground pressure for a 500-kg cow (Kubo \& Isobe 1975).

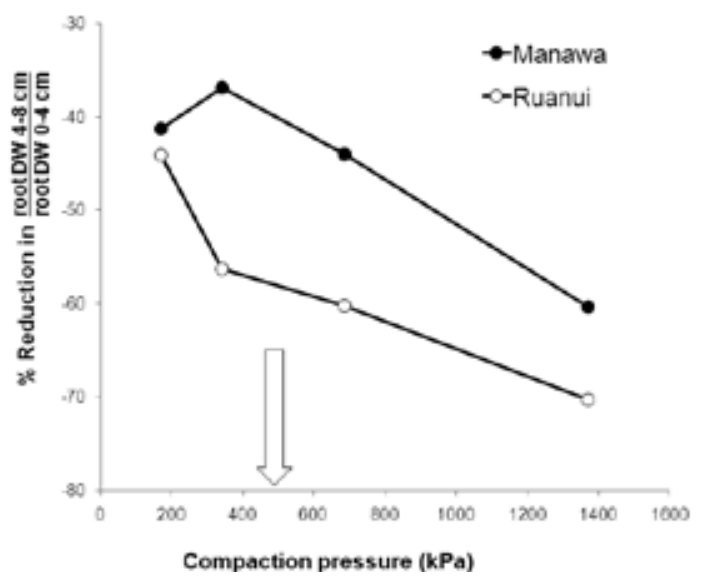

consequent effects on pasture (Edmond 1970; Climo \& Richardson 1984; Ledgard et al. 1996; Singleton et al. 2000; Menneer et al. 2004). Because of the lubricating effect of water on soil under compression, drainage characteristics of soils are critical in determining the severity of treading damage. Where soils are known to be susceptible to treading damage under wet conditions, moving stock from pasture before damage is severe has become established good practice (Thom et al. 1985; Bilotta et al. 2007). Ryegrass pulling, usually a summer phenomenon, also varies with soil type - Te Rapa peaty silt loam being worse than Te Kowhai silt loam (Thom et al. 2003). A compacted layer between 7 and $10.5 \mathrm{~cm}$ below the surface with $80 \%$ of root mass located in the top $5 \mathrm{~cm}$ was reported for both these soils by Houlbrooke (1996); presumably the lower strength of the peaty soil provided poorer anchorage than in the mineral soil. No broad systematic study of differences among soil types in susceptibility to pasture pulling has been found. Such information would enable development of technologies to mitigate pulling.

Research on the recovery of pasture soils from treading damage was reviewed by Drewry (2006). Soils do recover naturally over a period of months to years depending on the soil type, the severity of the damage, and post-damage management of the site. Rotationally grazed North Island dairy farms, where the stock are on the farm all year round, may be at risk of cumulative treading damage with inadequate spelling for recovery to occur. Beneficial responses on soil physical properties from mechanical loosening have been widely reported (Houlbrooke 1996; Burgess 1998; Drewry \& Paton 2000; Drewry et al. 2000b; Burgess et al. 2000), but only a few studies have included studies of root responses. Harrison et al. (1994) showed that subsoiling resulted in a greater $(36 \%)$ root length below $30 \mathrm{~cm}$ depth and increases in spring pasture growth on a dryland Templeton soil. Decision support tools and best practice guidelines for mechanical treatment of compacted pasture soils are required.

\section{Managing forage plant traits}

There is a strong relationship between larger root diameters and the ability of different plant species to penetrate compacted soil layers (Materechera et al. 1992). Ryegrass is poorly adapted to growing roots through compacted soil because of its relatively fine roots. Some genetic differences among ryegrasses have been noted for root response to impeded soil (Edmond 1958, Fig. 1; Houlbrooke et al. 1997), and for growth of ryegrass roots through a high-strength root medium (Crush et al. 2002). However, research on genetic variation in root morphology with the aim of developing grasses with superior root traits is a recent development (Crush \& Nichols 2010), and is yet to impact on cultivar development. Tall fescue has a reputation for deeprooting, and fescue cultivars capable of growing roots into the subsoil have thicker roots than surface rooting types (Torbert et al. 1990), confirming the importance of root diameter for root penetration. However, the roots of New Zealand ryegrass and tall fescue cultivars are quite similar (Crush et al. 2005), so a change of species may not provide a quick fix to the compaction/ pulling problem.

Relationships between soil compaction, root impedance, and pasture pulling seem obvious but are unproven. Interacting factors such as differences in soil strength (anchorage related to soil types), the shear strength of leaves and root weakening by insect larvae (Thom et al. 1996; 1998; 2003) will all contribute to observed differences in pulling rates.

\section{Nutrient management}

Increasing phosphate fertiliser inputs can offset the negative effects of soil compaction on pasture growth (Mackay et al. 2010) indicating that impeded root growth reduces access to soil nutrients. Any nutrient limitations will reduce the fitness of pasture plants and their ability to cope with other stresses. Compensating for the effects of soil compaction by increasing phosphate inputs has negative economic and environmental footprint implications. A better option than the common practice of applying basic fertiliser annually may be to use repeated applications at lower rates - fertilising each crop of grass as it is grown. This would reduce the amplitude of the change over time from nutrient luxury to progressive impoverishment and mal-adjusted herbage nutrient ratios, inherent 
with annual fertiliser inputs. It would also provide opportunities to tailor inputs to sward requirements e.g. higher $\mathrm{P}: \mathrm{N}$ input ratios during the clover growing season, and animal requirements such as increased magnesium in early lactation. From trials on nine pasture soils in Victoria, Burkitt et al. (2002) concluded that smaller, more frequent applications of phosphate may result in more effective increases in extractable $\mathrm{P}$ than the equivalent rate applied annually. Many farmers currently apply $\mathrm{N}$ fertiliser post-grazing suggesting that extending this practice to use of compound fertilisers should be investigated in a study that includes economic and environmental cost/benefit analyses.

\section{Reducing hoof impacts}

Pressures of $490 \mathrm{kPa}$ can be exerted by a front foot of a 500-kg cow (Kubo \& Isobe 1975), and this is more than enough to compact wet soil to a point where ryegrass root growth is reduced (Fig. 1). No consideration seems to have been given to breeding stock with larger hoof surface areas to reduce ground pressures. There is evidence for sire effects on hoof area in Angus beef animals (Morris \& Baker 1988), and an investigation of the potential to breed dairy cows with big, flat feet is warranted. The mechanical hoof used by Di et al. (2001) to simulate animal treading could be modified to investigate hoof-size impacts on soils. Fitting stock with shoes that increase the soil contact area and reduce ground pressures was suggested as a strategy to reduce soil damage by Wind \& Schothorst (1964). The idea was not taken any further but development of veterinary cattle shoes suggests that fitting cows with low groundpressure shoes may be worth investigating.

\section{Future Directions}

There is unlikely to be a single simple solution to the problems associated with soil compaction. A key point is that better management of the pastoral soil resource is required. Grazing strategies and tools to protect soil physical properties as described for a Southland dairy farm by Houlbrooke et al. (2009), need to be researched and adopted nationally. Detailed withinfarm soil mapping combined with farmer experience could identify the most susceptible paddocks that should be grazed early in the winter rotation. Under wet conditions, getting stock off at-risk soils and onto pads or herd homes will reduce rates of compaction. Best practice guidelines and decision support tools for mechanical treatment of soil compaction should be developed for major regional soil types.

Research underpinning cultivar development needs to investigate genetic variation in root traits such as diameter (for penetration of compacted soils) and tensile strength (resistance to pulling forces during grazing). Protection of plants from insect damage by appropriate use of Neotyphodium shoot endophytes and the effect on roots is discussed in Popay \& Hume (2011, this volume). In the longer term, better soil husbandry and better adapted pasture grasses should contribute to improved pasture persistency.

\section{ACKNOWLEDGEMENT}

We thank Lily Ouyang for preparation of Figure 1 and two anonymous referees for helpful comments.

\section{REFERENCES}

Bilotta, G.S.; Brazier, R.E.; Haygarth, P.M. 2007. The impacts of grazing animals on the quality of soils, vegetation, and surface waters in intensively managed grasslands. Advances in Agronomy 94: 237280.

Burgess, C.P. 1998. Effects of livestock treading and mechanical loosening of soil on soil physical properties and pasture. Unpublished MSc thesis, University of Waikato, $239 \mathrm{pp}$.

Burgess, C.P.; Chapman, R.; Singleton, P.L.; Thom, E.R. 2000. Shallow mechanical loosening of a soil under dairy cattle grazing: Effects on soil and pasture. New Zealand Journal of Agricultural Research 43: 279-290.

Burkitt, L.L.; Gourley, C.J.P.; Sale, P.W.G. 2002. Changes in bicarbonate-extractable phosphorus over time when P fertiliser was withheld or reapplied to pasture soils. Australian Journal of Soil Research 40: 1213-1229.

Chapman, R.; Allbrook R.F. 1987. The effects of subsoiling compacted soils under grass - a progress report. Proceedings of the Agronomy Society of New Zealand 17: 55-58.

Charles, A.H. 1979. Treading as a factor in sward deterioration. In: Changes in sward composition and productivity. Eds. Charles, A.H.; Haggar, R.J. British Grassland Society, Occasional Symposium 10: 137140.

Climo, W.J.; Richardson, M.A. 1984. Factors affecting the susceptibility of three soils in the Manawatu to stock treading. New Zealand Journal of Agricultural Research 27: 247-253.

Crush, J.R.; Ouyang, L.; Eerens, J.P.J.; Stewart, A.V. 2002. The growth of roots of perennial, Italian, hybrid and annual ryegrasses through a high-strength root medium. Grass and Forage Science 57: 322328.

Crush, J.R.; Waller, J.E.; Care, D.A. 2005. Root distribution and nitrate interception in eleven temperate forage grasses. Grass and Forage Science 60: 385-392.

Crush, J.R.; Nichols, S.N. 2010. Progress towards 
forage plant root systems for sustainable dairying. pp. 50-52. In: Proceedings of the $4^{\text {th }}$ Australasian Dairy Science Symposium.

Di, H.J.; Cameron, K.C.; Milne, J.; Drewry, J.J.; Smith, N.P.; Hendry, T.; Moore, S.; Reijnen, B. 2001. A mechanical hoof for simulating animal treading under controlled conditions. New Zealand Journal of Agricultural Research 44: 111-116.

Drewry, J.J.; Littlejohn, R.P.; Paton, R.J. 2000a. A survey of soil physical properties on sheep and dairy farms in southern New Zealand. New Zealand Journal of Agricultural Research 43: 251-258.

Drewry, J.J.; Paton, R.J. 2000. Effect of subsoiling on soil physical properties and dry matter production on a brown soil in Southland, New Zealand. New Zealand Journal of Agricultural Research 43: 259268.

Drewry, J.J.; Lowe, J.A.H.; Paton, R.J. 2000b. Effect of subsoiling on soil physical properties and pasture production on a pallic soil in Southland, New Zealand. New Zealand Journal of Agricultural Research 43: 269-277.

Drewry, J.J. 2006. Natural recovery of soil physical properties from treading damage of pastoral soils in New Zealand and Australia: a review. Agriculture, Ecosystems and Environment 114: 159-169.

Drewry, J.J.; Cameron, K.C.; Buchan, G.D. 2008. Pasture yield and soil physical property responses to soil compaction from treading and grazing - a review. Australian Journal of Soil Research 46: 237256.

Dunbabin, V.; Diggle, A.; Rengel, Z. 2003. Is there optimum root architecture for nitrate capture in leaching environments? Plant, Cell and Environment 26: 835-844.

Edmond, D.B. 1958. Some effects of soil physical condition on ryegrass growth. New Zealand Journal of Agricultural Research 1: 652-659.

Edmond, D.B. 1970. Effects of treading on pastures, using different animals and soils. pp. 604-608. In: Proceedings of the $11^{\text {th }}$ International Grassland Congress.

Federer, C.A.; Tenpas, G.H.; Schmidt, D.R.; Tanner, C.B. 1961. Pasture soil compaction by animal traffic. Agronomy Journal 53: 53-54.

Gradwell, M.W. 1967. Soil physical conditions of winter and the growth of ryegrass plants II. Effects of soil atmosphere. New Zealand Journal of Agricultural Research 10: 425-434.

Harrison, D.F.; Cameron, K.C.; McLaren, R.G. 1994. Effects on subsoil loosening on soil physical properties, plant root growth, and pasture yield. New Zealand Journal of Agricultural Research 37: 559567.
Houlbrooke, D.J. 1996. Subsoiling and soil compaction effects on soil physical properties and pasture response. Unpublished MSc thesis, University of Waikato, 155 pp.

Houlbrooke, D.J.; Thom, E.R.; Chapman, R.; McLay, C.D.A. 1997. A study of the effects of soil bulk density on root and shoot growth of different ryegrass lines. New Zealand Journal of Agricultural Research 40: 429-435.

Houlbrooke, D.J.; Drewry, J.J; Monaghan, R.M.; Paton, R.J.; Smith, L.C.; Littlejohn, R.P. 2009. Grazing strategies to protect soil physical properties and maximise pasture yield on a Southland dairy farm. New Zealand Journal of Agricultural Research 52: 323-336.

Kubo, S.; Isobe, S. 1975. Treading on grassland: hoof pressure by unrestrained walk. Bulletin of the National Grassland Research Institute 7: 33-38.

Ledgard, S.F.; Thom, E.R.; Singleton, P.L.; Thorrold, B.S.; Edmeades, D.C. 1996. Environmental impacts of dairy systems. pp. 26-33. In: Proceedings $48^{\text {th }}$ Ruakura Farmers' Conference.

Lorenz, K.; Lal, R. 2005. The depth distribution of soil organic carbon in relation to land use and management and the potential of carbon sequestration in subsoil horizons. Advances in Agronomy 88: 35-66.

Mackay, A.D. 2008. Impacts of intensification of pastoral agriculture on soils: current and emerging challenges and implications for future land uses. New Zealand Veterinary Journal 56: 281-288.

Mackay, A.D.; Gillingham, A.; Smith, C.; Budding, P.; Phillips, P.; Clarke-Hill, W.; Johnstone, P. 2010. Evaluation of the effects of grass species, irrigation, nitrogen fertiliser application and soil compaction on the response of modern dairy pastures to phosphorus fertiliser. Proceedings of the New Zealand Grassland Association 72: 153-158.

Materechera, S.A.; Alston, A.M.; Kirby, J.M.; Dexter, A.R. 1992. Influence of root diameter on the penetration of seminal roots into a compacted subsoil. Plant and Soil 144: 297-303.

Menneer, J.C.; Ledgard, S.; McLay, C.; Silvester, W. 2004. The impact of grazing animals on $\mathrm{N}_{2}$ fixation in legume-based pastures and management options for improvements. Advances in Agronomy 83: 181-241.

Menneer, J.C.; Ledgard, S.; McLay, C.; Silvester, W. 2005. The effects of treading by dairy cows during wet soil conditions on white clover productivity, growth and morphology in a white clover - perennial ryegrass pasture. Grass and Forage Science 60: 4658.

Morris C.A.; Baker, R.L. 1988. Foot scores of cattle 2. Relationships among measurements of feet from slaughtered steers from eight sire groups. New 
Zealand Journal of Agricultural Research 31: 21-25. Mullen, G.J.; Jelley, R.M.; McAleese, D.M. 1974. Effects of animal treading on soil properties and pasture production. Irish Journal of Agricultural Research 13: 171-180.

Popay, A.J.; Hume, D.E. 2011. Endophytes improve ryegrass persistence by controlling insects. Pasture Persistence. Grassland Research and Practice Series 15: 149-156.

Sears, P.D. 1956. The effect of the grazing animal on pasture. pp. 92-103. In: Proceedings of the $\mathrm{V} 11^{\text {th }}$ International Grassland Congress.

Singleton, P.L.; Addison, B. 1999. Effects of cattle treading on physical properties of three soils used for dairy farming in the Waikato, North Island, New Zealand. Australian Journal of Soil Research 37: 891-902.

Singleton, P.L.; Boyes, M.; Addison, B. 2000. Effect of treading by dairy cattle on topsoil physical conditions for six contrasting soil types in Waikato and Northland, New Zealand, with implication for monitoring. New Zealand Journal of Agricultural Research 43: 559-567.

Thom, E.R.; Thomson, N.A.; Clayton, D.G. 1985. Establishment and management of suitable species in dairy pastures. Grassland Research and Practice Series 3: 71-75.

Thom, E.R.; Van Vught, V.T.; McCabe, R.J. 1996. Growth and persistence of perennial ryegrass lines with different tolerances to "pulling" during grazing. Proceedings of the New Zealand Grassland
Association 58: 67-72.

Thom, E.R.; Waugh, C.D.; McCabe, R.J. 1998. Growth and persistence of perennial and hybrid ryegrasses lines when grazed by dairy cows in the central Waikato region of New Zealand. New Zealand Journal of Agricultural Research 41: 477-486.

Thom, E.R.; Burggraaf, V.T.; Watts, R.J.; Hooper, R.J. 2003. Relationship of tillering and morphological characteristics of two perennial ryegrass lines to "pulling" when grazed by cows. New Zealand Journal of Agricultural Research 46: 15-25.

Torbert, H.A.; Edwards, J.H.; Pedersen, J.F. 1990. Fescues with large roots are drought tolerant. Applied Agricultural Research 5: 181-187.

Willat, S.T.; Pullar, D.M. 1984. Changes in soil physical properties under grazed pastures. Australian Journal of Soil Research 22: 343-348.

Wind, G.P.; Schothorst, C.J. 1964. The influence of soil properties on suitability for grazing and of grazing on soil properties. pp. 571-580. In: Proceedings of the Eighth International Congress of Soil Science.

Zegwaard, K.E. 2006. Effects of severe cattle treading on soil physical properties and pasture productivity. Unpublished $\mathrm{PhD}$ thesis, University of Waikato. 522 pp. 
